\title{
A new freshwater species of Saccardoella from Hong Kong and South Africa
}

K. M. Tsui

K. D. Hyde ${ }^{1}$

I. J. Hodgkiss

T. K. Goh

Department of Ecology and Biodiversity, The University of Hong Kong, Pokfulam Road, Hong Kong

Abstract: Saccardoella aquatica sp. nov. occurring on wood submerged in streams in Hong Kong and South Africa is described and illustrated with differential interference micrographs. This species produces long, cylindrical asci and 3-septate ascospores surrounded by a mucilaginous sheath, and differs from other species in Saccardoella in having fusiform ascospores. A key and synopsis of Saccardoella species are provided.

Key Words: Ascomycetes, aquatic fungi, lignicolous fungi, systematics

During a survey of fungi found on submerged wood in streams in Hong Kong and South Africa, a new species belonging to Saccardoella was found. It is unique in producing fusiform, 3-septate, heavily guttulate ascospores surrounded by an inconspicuous sheath. It is here described as $S$. aquatica sp. nov. and illustrated with differential interference micrographs.

Saccardoella aquatica K. M. Tsui, K. D. Hyde, I. J. Hodgkiss \& Goh, sp. nov. $\quad$ FIGs. 1-11

Ascomata $560-700 \mu \mathrm{m}$ alta, nigra, $640-720 \mu \mathrm{m}$ diam., erumpentia vel immersa, globosa vel subglobosa, papillata, ostiolata, coriacea, carbonacea, solitaria vel gregaria. Clypeata $10-6 \mu \mathrm{m}$ crassa, ostiolum circum crassiora. Papilla conica, 125 $\mu \mathrm{m}$ alta, $150 \mu \mathrm{m}$ in diam., periphysata. Peridium $20-30 \mu \mathrm{m}$ crassum, ostiolum circum crassiora, Asci $185-230 \times 7-9 \mu \mathrm{m}$, $(\bar{x}=204.2 \times 7.9 \mu \mathrm{m}, \mathrm{n}=30)$, 8-spori, longe cylindrici vel filiformis, unitunicati, pedicellati, apparato apicali praediti. Ascosporae $26-34 \times 6-8 \mu \mathrm{m}(\bar{x}=29.2 \times 7 \mu \mathrm{m}, \mathrm{n}=50)$, uniseriatae, late fusiformes, 3-septatae, ad septa constrictae, hyalinae, tunico gelatinoso praeditae.

Accepted for publication February 20, 1998

${ }^{1}$ Corresponding author, email: kdhyde@hkucc.hku.hk
Etymology. in reference to the freshwater habitat where this species was found.

HOLOTYPE. HONG KONG. New Territories, Tai Po, Lam Tsuen River, on submerged wood, 22 Jan. 1997, K. M. Tsui, KM56 (HKU(M) 5371).

Colonies on potato dextrose agar superficial, cottony, white at the center, pale brown towards the margin; Reverse dark brown, growing in concentric rings, black in the center. No fruiting bodies or anamorphs formed in culture. Ascomata on natural substratum shiny, dark brown to black, $560-700 \mu \mathrm{m}$ high, $640-720 \mu \mathrm{m}$ diam, immersed or erumpent, globose or subglobose, papillate, ostiolate, coriaceous, carbonaceous, solitary to gregarious (FIGS. 1,2). Clypeus extending outwards around the ascomata, 10-60 $\mu \mathrm{m}$ thick, thicker around the papilla, composed of dense, melanised cells in the host tissue (Figs. 1, 5). Papilla blunt conical, up to 125 $\mu \mathrm{m}$ high, $150 \mu \mathrm{m}$ diam, brown with periphyses (FIG. 1). Peridium 20-30 $\mu \mathrm{m}$ wide, wider around the ostiole, composed of two strata: an inner stratum of three to five layers composed of angular brown thin-walled cells forming a textura angularis, and an outer stratum composed of fungal hyphae interspersed with host cells forming a textura intricata (FIG. 5). Paraphyses numerous, 2-3 $\mu \mathrm{m}$ diam, filamentous and hypha-like (FIG. 11). Asci 185-230 $\times 7-9 \mu \mathrm{m}(\bar{x}=204.2 \times 7.9 \mu \mathrm{m}, \mathrm{n}=30), 8$-spored, long-cylindrical or filiform, short-pedicellate, with an apical ring (FIGs. 3-4, 6). Ascospores 26-34 $\times$ 6-8 $\mu \mathrm{m}(\bar{x}=29.2 \times 7.0 \mu \mathrm{m}, \mathrm{n}=50)$, overlapping uniseriate, fusiform, with acute ends, 3-septate, constricted at the septa, hyaline, surrounded by an inconspicuous mucilaginous sheath (FIGS. 7-10).

Habitat. Saprobic on submerged wood.

Known distribution. Hong Kong, South Africa.

Other material examined. Hong Kong. New Territories, Tai Po, Lam Tsuen River, on submerged wood, 22 Jan. 1997, K. M. Tsui, KM56 (HKU(M) 5372); South Africa, Durban, Palmet River, on submerged wood, Nov. 1994, K. D. Hyde and T. S. Steinke, KM56 (HKU(M) 2202).

Saccardoella aquatica bears some resemblance to S. marinospora K. D. Hyde and S. macrasca (Sacc.) M. E. Barr which also produce 3-septate ascospores (Hyde, 1992; Barr, 1994). Saccardoella macrasca has consistently smaller asci and ascospores, and is unique in having more fusiform, distoseptate as- 

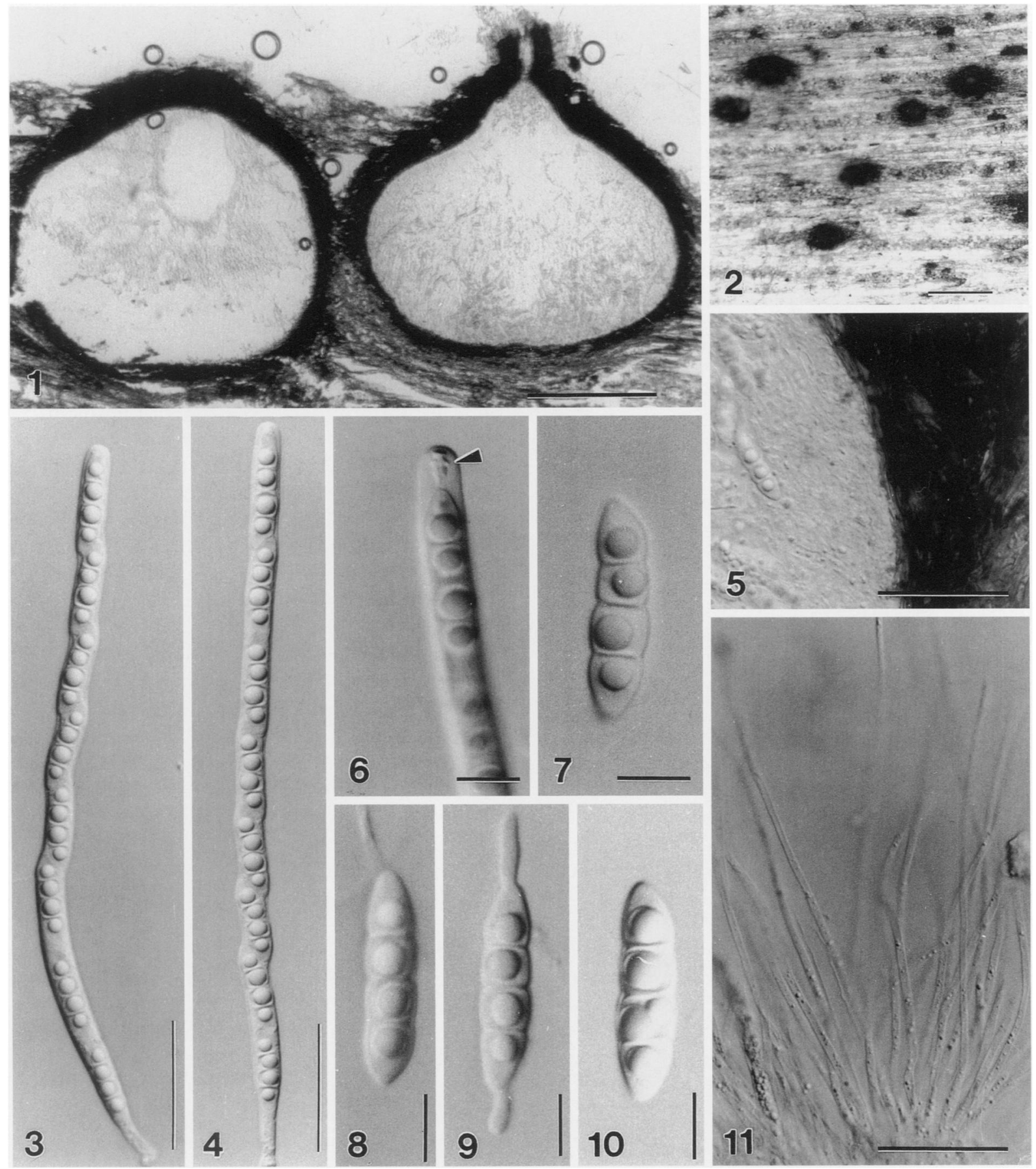

Figs. 1-11. Interference micrographs of Saccardoella aquatica (from holotype) 1. Section of the ascomata. 2. Appearance of ascomata on submerged wood. 3, 4. Asci. 5. Section of the peridium. 6. Close-up of the ascus apex. Note the subapical apparatus (arrowed). 7-10. Ascospores. 11. Paraphyses. Scale bars: $1=300 \mu \mathrm{m}, 2=400 \mu \mathrm{m}, 3-4=40 \mu \mathrm{m}, 5=50 \mu \mathrm{m}, 6-$ $10=10 \mu \mathrm{m}, 11=40 \mu \mathrm{m}$.

cospores which taper towards their apices and lack a mucilaginous sheath (Barr, 1994). Asci and ascospores of $S$. aquatica and $S$. marinospora are of similar dimensions but differ in a number of respects. S. aquatica has fusiform, 3-septate asco- spores, whereas in $S$. marinospora the ascospores are broadly ellipsoidal. Furthermore, ascospores in $S$. aquatica are constricted at the septa, while constrictions are absent in $S$. marinospora. The ascomata in $S$. aquatica are also smaller (560-700 $\mu \mathrm{m}$ 


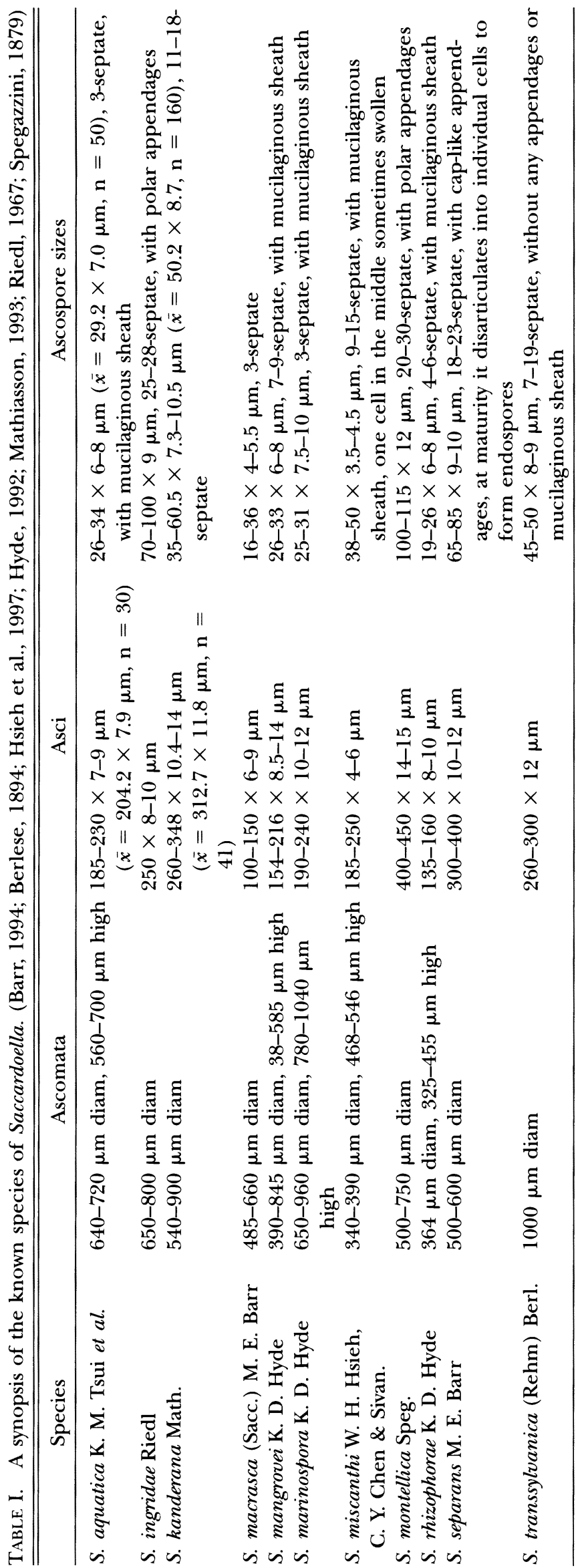

high, $640-720 \mu \mathrm{m}$ diam) when compared to $S$. marinospora (780-1040 $\mu \mathrm{m}$ high, 650-960 $\mu \mathrm{m}$ diam). The ascus wall of $S$. aquatica is wide and similar to that found in other species of Saccardoella.

The genus Saccardoella is saprotrophic and widely distributed geographically, with species recorded from Austria, Australia, Brunei, Canada, Hong Kong, Norway, South Africa, Switzerland, Thailand, and USA, and species occur in terrestrial, aquatic and marine habitats. A mucilaginous sheath surrounding ascospores is found only in species reported from freshwater and marine habitats, i.e., $S$. aquatica, S. mangrovei K. D. Hyde, S. marinospora, and $S$. rhizophorae K. D. Hyde. The mucilaginous sheath may aid in the dispersal of ascospores and their attachment to substrates. The presence of lipid globules in the ascospores may facilitate ascospore flotation.

The genus Saccardoella has been revised by Barr (1994) who produced a key to North American species. A key to all published species and a synopsis of characters is given (TABLE I), however $S$. berberidis Eliasson, $S$. canadensis Ellis \& Everh. and S. dehliana are not included. Mathiasson (1993) concluded that the first two species are inseparable from $S$. transsylvanica (Rehm) Berl. We agree with Heish et al. (1997) that $S$. dehliana does not belong in this genus. In the description and illustration provided by Malhotra and Mukerji (1978), asci are typically loculoascomycetous.

\section{KEY TO SACCARDOELLA SPECIES}

1. Ascospores without a sheath or polar appendages .. 2

1. Ascospores with a mucilaginous sheath or polar ap-

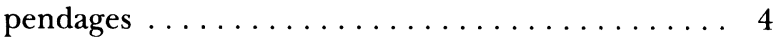

2. Ascospores 3-septate, fusiform in shape, and tapering at the apices ............ macrasca

2. Ascospores with more than 3 septa ....... 3

3. Ascospores 35-60.5 $\times$ 7.3-10.5 $\mu \mathrm{m}$, distinctly constricted at the central septum ....... S. kanderana

3. Ascospores 45-50 $\times 8-9 \mu \mathrm{m}$, not constricted at the central septum ............ S. transsylvanica

4. Ascospores with polar appendages ....... 5

4. Ascospores with a mucilaginous sheath ..... 7

5. Ascospores with long terminal appendages $\ldots \ldots 6$

5. Ascospores 65-85 $\times 9-10 \mu \mathrm{m}$, with 18-23 septa, constricted at the septum and having caplike appendages. At maturity, ascospores disarticulate into individual cells to form endospores ........ S. separans 6. Ascospores 70-100 $\times 9 \mu \mathrm{m}, 25-28$ septate $\ldots$. $\ldots \ldots \ldots \ldots \ldots \ldots$. ingridae 6. Ascospores $100-115 \times 12 \mu \mathrm{m}, 20-30$ septate $\ldots$. $\ldots \ldots \ldots \ldots \ldots \ldots \ldots \ldots$. montellica

7. Ascospores with more than 9 septa, 38-50 $\times 3.5-4.5$ $\mu \mathrm{m}$, with a swollen cells in the middle ... S. miscanthi

7. Ascospores with less than 10 septa ........ 8 8. Ascospores $26-33 \times 6-8 \mu \mathrm{m}, 7-9$ septate $\ldots \ldots$. 
8. Ascopores with fewer than 7 septa . . . . . . 9

9. Ascospores $19-26 \times 6-8 \mu \mathrm{m}, 4-6$ septate $\ldots \ldots \ldots$ $\ldots \ldots \ldots \ldots \ldots$ S. rhizophorae

9. Ascospore 3-septate . . . . . . . . . . 10

10. Ascospores $25-31 \times 7.5-10 \mu \mathrm{m}$, broadly ellipsoidal, not constricted at a septa . . . . . . S. marinospora

10. Ascospores $26-34 \times 6-8 \mu \mathrm{m}$, fusifom, constricted at septa .............. aquatica

\section{ACKNOWLEDGMENTS}

Helen Leung, Michelle Wong and A. Y. P. Lee are thanked for their technical and photographic assistance. Professor T. Steinke is thanked for his help in South Africa. K. M. Tsui would like to thank the Department of Ecology and Biodiversity for the award of a Part-time Demonstratorship.

\section{LITERATURE CITED}

Barr, M. E. 1994. Notes on the Amphisphaeriaceae and related families. Mycotaxon 51: 191-224.

Berlese, A. N. 1894. Icones Fungorum. I. Biblioth. Mycol. 16A: 1-243.

Hyde, K. D. 1992. The genus Saccardoella from intertidal mangrove wood. Mycologia 84: 803-810.

Malhotra, G., and K. G. Mukerji. 1978. Fungi of Delhi XXVIII. Four pyrenomycetes from bark. Trans. Mycol. Soc. Japan 19: 283-288.

Mathiassen, G. 1993. Corticolous and lignicolous pyrenomycetes s. lat. (Ascomycetes) along a mid-Scandinavian transect. Sommerfeltia 20: 1-180.

Hsieh, W. H., C. Y. Chen, and A. Sivanesan. 1997. Some new ascomycetes from Taiwan. Mycol. Res. 101: 897-907.

Riedl, V. H. 1967. Über eine neue Saccardoella-Art aus Niederösterreich. Sydowia 21: 272-276.

Spegazzini, C. 1879. Nova addenda ad mycologiam venetam. Michelia 1: 453-487. 